\title{
Evolution of Public Financial Management in Bhutan
}

\author{
Sonam Tobgyel
}

\author{
Accounts Division, Department of Public Accounts, Ministry of Finance, Thimphu, Bhutan \\ stobgyel@mof.gov.bt \\ Received: 10 May 2021; Received in revised form: 12 Jun 2021; Accepted: 18 Jun 2021 \\ (C2021 The Author(s). Published by TheShillonga. This is an open access article under the CC BY license \\ (https://creativecommons.org/licenses/by/4.0/)
}

\begin{abstract}
The purpose of this paper is to assess how the Public Financial Management (PFM) in the country has evolved over the years. Public Financial Management refers to the sets of laws, rules, systems and processes used by sovereign nations, to mobilize revenue, allocate public funds, and undertake public spending, account for funds and audit results.

An effective Public Financial Management (PFM) system are required to maximize the efficient use of resources, create the highest level of transparency and accountability in government finances and to ensure long term economic success. A strong public financial management system are essential to improve service delivery, poverty reduction and to achieve the Millennium Development Goals (MDGs).

The evolution of public financial management system in the Royal Government of Bhutan (RGoB) had its grass roots in the efforts of the third hereditary king (1952 to 1972) to expand and modernize the structure of Government and of society itself. The paper covers the public financial management in Bhutan in a chronological sequence since 1950s until the present period. It provides the readers with information on how the PFM in the country has evolved over the decades to meet the needs of the changing time.
\end{abstract}

The PFM landscape in the country has undergone sea change from the manual system to online-web-based system and will continue to improve and change for the betterment in keeping with the technological advancement in the world in the $21^{\text {st }}$ century era.

Keywords-Accountability; Decentralization; Economy; Effectiveness; Efficiency; Five Year Plan; Good Governance; Public Financial Management; Public Fund; Transparency.

\section{INTRODUCTION}

Public Financial Management (PFM) refers to the sets of laws, rules, systems and processes used by sovereign nations, to mobilize revenue, allocate public funds, and undertake public spending, account for funds and audit results. It encompasses a broader set of functions than financial management and is commonly conceived as a cycle of six phases, beginning with policy design and ending with external audit and evaluation.

An effective Public Financial Management (PFM) system are required to maximize the efficient use of resources, create the highest level of transparency and accountability in government finances and to ensure long term economic success. A strong public financial management system are essential to improve service delivery, poverty reduction and to achieve the Millennium Development Goals (MDGs). Activities range from the preparation and fulfillment of the budget cycle, budget oversight and control, taxing and debt management and procurement, to resource allocation and income distribution.

The evolution of public financial management system in the Royal Government of Bhutan (RGoB) had its grass roots in the efforts of the third hereditary king (1952 to 1972) to expand and modernize the structure of Government and of society itself. In 1961 an Accounts and Audit Committee was established called the Gyaltse Kha Lowa ${ }^{1}$.

- The Gyaltse Kha Lowa comprised of four members;

- $\quad$ one representative of His Majesty the King and

${ }^{1}$ Ministry of Finance www.mof.gov.bt 
- $\quad$ one representative each from the Cabinet, Public and the Monk Body

The Committee was responsible for the proper maintenance of revenue and government properties.

During the First Plan a major portion of the effort was expended establishing the necessary machinery for carrying out the development programme, such as the establishment of the Development Wing Headquarters with the Secretary General in charge, assisted by the Director of Administration and a Secretary as well as a Financial Adviser and Chief Accounts Officer ${ }^{2}$. The Financial Adviser and Chief Accounts Officer function in a dual capacity both as Financial Adviser to the Secretary General and as Accounts and Audit Officer for watching the expenditure of the various Development Wing Departments.

The Wing had 10 departments viz: Agriculture, Animal Husbandry, Forest and Soil Preservation, Power, Industry, Mineral Development, Roads (Bhutan Engineering Services), Road Transport and Telephones, Education and Health.

\section{FINANCIAL MANUALS/RULES}

\subsection{Manual of Financial Accounting and Services Rules 1963}

The organization of the Wing and that of the financial system under an Audit and Accounts Organization were formalized with the issuance of the first edition of the Manual of Financial Accounting and Services Rules in two parts in 1963.

Part I covered financial management, particularly arrangements for provision of funds, financial principles, the system of financial management and control, receipts and withdrawal of money, budget and appropriation works, works other than Bhutan engineering services, contracts, store, staff cars and government vehicles for departmental use, and some miscellaneous provisions.

Part II covered service rules, particularly classification and creation of posts, requirements on first appointment and general conditions, fixation of pay, increments, leave, joining time, traveling allowance and medical aid.

The 1963 Manual was updated and revised in 1971 to suit the changes in the structure of the Government and the increase in government activities, conformably with the Five Year Plans (FYPs).

His Majesty the Fourth Druk Gyalpo, who began his reign in 1972, vowed to continue to work on the path set by his father and predecessor, and updated and expanded the FiveYear Plans. Five-year planning, as a system, has been institutionalized to provide direction for the Government in administering the affairs of the kingdom towards social and economic reliance, stability and progress, enriched with tradition and culture.

Modern public finance practices in Bhutan can be said to have begun in the early 1970s. Prior to this, most taxes were being collected in kind in the form of agricultural produce or as labor and the burden in either case was quite heavy. The levy on produce was on an average one fourth of production of each farming family and labor contribution amounted to about two month's labor for every adult. With the introduction of cash taxes based on type of land holding and on livestock, the burden on the population decreased sharply. However, labor contribution continued and formed a significant input in construction in the first two Five Year Plans.

\subsection{Financial Manual 1975}

To keep up with the programs of the Government under the five-year plans, the financial system was further updated in a Financial Manual issued in 1975. The Manual covered financial management and service rules, particularly general principles governing expenditures; the government financial organization; the Bhutan Civil Service Rules; the budget; sanctions and control of expenditures including delegation of powers; compilation of accounts; audit; and arrangement for cash, payment of claims, stores, etc. The service rules concerned matters such as emoluments, allowances, and employee benefits.

\subsection{Financial Organization (1975)}

The financial organization in the Royal Government of Bhutan was concentrated in the Ministry of Finance under the representative of His Majesty as shown below:

\footnotetext{
2 II Five Year Plan document, GNHC www.gnhc.gov.bt
} 


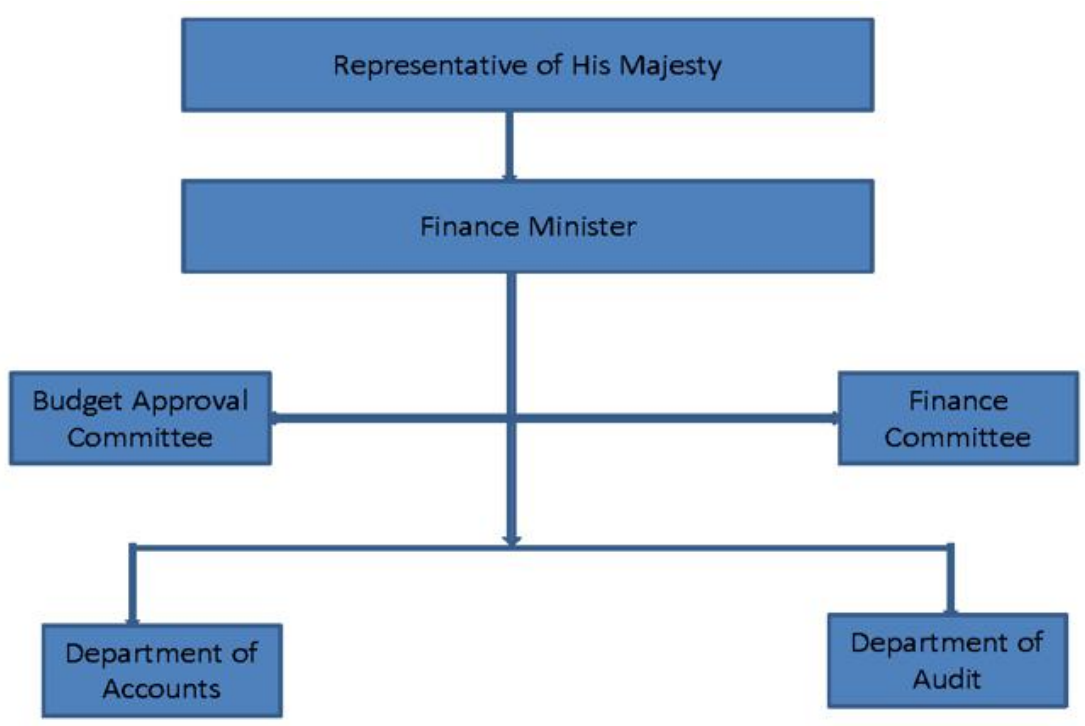

Fig.1: Financial Organization (1975)

The functions and composition of the Committees and the Departments are summarized as below:

\begin{tabular}{|c|c|c|c|}
\hline $\begin{array}{l}\text { Sl. } \\
\text { No. }\end{array}$ & $\begin{array}{l}\text { Committee/ } \\
\text { Department }\end{array}$ & Function & Member Composition \\
\hline 1 & $\begin{array}{l}\text { Finance } \\
\text { Committee }\end{array}$ & - Assist in policy decisions/matters & $\begin{array}{l}\text { i. } \text { Chairman - Finance Minister } \\
\text { ii. Dy. Chairman - Finance Secretary } \\
\text { iii. Members: } \\
\text { - Secretary of Planning Commission } \\
\text { - Economic Advisor } \\
\text { - Chief Accounts Officer } \\
\text { - Chief Audit Officer }\end{array}$ \\
\hline 2 & $\begin{array}{l}\text { Budget } \\
\text { Approval } \\
\text { Committee }\end{array}$ & $\begin{array}{l}\text { - Decides the budgetary proposals of each } \\
\text { ministry } \\
\text { - Submit recommendations to the Minister } \\
\text { of Finance, for consolidation of proposals } \\
\text { and final approval by the Planning } \\
\text { Commission and the Head of the } \\
\text { Government }\end{array}$ & $\begin{array}{l}\text { i. Secretaries of the Government } \\
\text { ii. Advisors of the Government }\end{array}$ \\
\hline 3 & $\begin{array}{l}\text { Department of } \\
\text { Accounts }\end{array}$ & $\begin{array}{l}\text { - Responsible for the preparation of the } \\
\text { annual budget, expenditure controls, } \\
\text { interpretation of the rules and regulations, } \\
\text { consolidation } \\
\text { - Submission of accounts, taxation policy, } \\
\text { collection of revenues, currency and } \\
\text { coinage, banking, and customs and excise }\end{array}$ & $\begin{array}{l}\text { i. Finance Secretary, assisted by the Chief } \\
\text { Accounts Officer (concurrently under the } \\
\text { direct administrative control of the Finance } \\
\text { Minister) } \\
\text { ii. Under the Department are a number of sub- } \\
\text { units, each headed by a finance and accounts } \\
\text { officer }\end{array}$ \\
\hline 4 & $\begin{array}{l}\text { Department of } \\
\text { Audit }\end{array}$ & $\begin{array}{l}\text { - Responsible for the audit of expenditures } \\
\text { and revenues of the Government. }\end{array}$ & $\begin{array}{l}\text { i. Deputy Auditor General, assisted by Chief } \\
\text { Audit Officer (concurrently under the direct }\end{array}$ \\
\hline
\end{tabular}




\begin{tabular}{|l|l|l|}
\hline & & $\begin{array}{l}\text { administrative control of the Minister of } \\
\text { Finance) }\end{array}$ \\
ii. $\begin{array}{l}\text { Though accredited to the Ministry of Finance, } \\
\text { the Deputy Auditor General was required to } \\
\text { submit his annual audit report directly to the } \\
\text { Representative of His Majesty in the Ministry. }\end{array}$
\end{tabular}

\subsection{Budget Process (1975)}

The budget process covered the preparation, submission, and approval of (a) detailed estimated expenditures by each ministry, and (b) the estimated revenue receipts of the Government. The expenditures were classified under the three broad categories, namely:

(i) Maintenance expenditure - which included expenses for salaries and allowances, investment necessary to continue a particular programme or scheme, maintenance of existing buildings and equipment etc.

(ii) Spill-over expenditure - which constituted that part of expenditure committed from previous year(s)

(iii) Schedule of new demands - which constituted that part of expenditure pertaining totally to new schemes/projects/programs on which no expenditure had been incurred in previous years

The institutionalization of public finance has also been originated later although a position of Finance Secretary was created within the Royal Secretariat in 1963. It was only in 1968 that the Ministry of Finance was formed and in 1971 that the first budget was prepared. This budget was the "Civil Budget" as it catered only to the needs of nondevelopmental organizations - the Royal Secretariat and Ministries of Finance, Home and Foreign Affairs. A separate "Development Budget" which was outside the purview of the Finance Ministry and administered by the Development Secretariat served the development departments.

The primary function of this budget was to allocate the annual grants from the Government of India (GoI). This situation continued for a long time, as there were practically no financial links between the two budgets. However, in 1980/81, the two budgets were integrated into streamline budgetary procedures and also in anticipation of the larger contribution, internal resources were expected to make in the Fifth Plan.

One of the important aims of the principle of self-reliance enunciated by His Majesty the Fourth Druk Gyalpo is to attempt to meet the recurring cost of Government, at least of all essential services, by domestic resources

\footnotetext{
${ }^{3}$ V Five Year Plan document, www.gnhc.gov.bt
}

mobilization. This calls for not only raising internal resources, but also curtailing excessive growth of recurring expenditure through effective budgetary practices and optimization of organization strength.

Although major contributions to domestic resources in the Fifth Plan are expected to come from the revenue generating investments and the streamlining of existing commercial activities, there is no doubt that fiscal policies, especially taxation measures, could yield significant revenues from the expanding tax base that will emerge out of the growth of economic activity in the Fifth Plan and the streamlining of tax administration. It is recognized that the taxation system would have to be carefully expanded in order to protect fledgling activities and the more vulnerable sections of the population and it is necessary to devise taxation measures that are simple and effective. The Government has, therefore, initiated a comprehensive study with the help of the Indian Institute of Public Finance and Policy and the International Monetary Fund (IMF) to devise comprehensive taxation proposals, legislation and suitable administrative measures. A Revenue Cell in the Ministry of Finance was already functioning and a decision has been taken to constitute a regular Revenue Service for tax administration. While the studies referred to above would have helped in devising taxation policy and measures, a number of new measures have already been put into effect by $1982 / 83^{3}$.

Budgetary procedures are expected to play a significant role in cutting costs and in making more efficient use of available resources. Especially with the re-organization of Government and decentralization, modifications of control procedures have become necessary. It is Government's feeling that many elements of the budgetary control mechanism devised earlier have become obsolete; procedures originally formulated when the size of Government was small and compact are no longer effective with the increasing size and dispersed nature of Government. Reforms have been initiated in the Fifth Plan in three major areas - namely, in the consolidation of the dual budgetary system, in the definition of financial powers and in revenue collection and disbursement procedures. 
Beginning with 1981/82, the civil and development budgets were consolidated into a single entity and the Budget Bureau to formulate and administer the overall budget, was created under the Ministry of Finance. The Bureau formulates and oversees the budget of the entire Government. Supplementing this, the roles of the Ministries of Finance and Foreign Affairs (MoFA) and the Planning Commission have been rationalized. The Ministry of Finance, apart from responsibility for the entire budget, also has overall responsibility for domestic resource mobilization. In assessing resource requirements and expenditure, the Ministry of Finance closely coordinated with the Planning Commission, the latter ensuring that expenditure proposals are consistent with plan priorities. The mobilization of foreign aid is conducted through the Ministry of Foreign Affairs.

The other major reform initiated in 1982/83 is in disbursement and revenue collection. Prior to this, each department had its own accounts into which Government transferred funds against the budgetary requirement on a quarterly basis. Besides, each department also had a separate account into which revenues earned were deposited for subsequent remittance to the Ministry of Finance. It was realized that this system had a major drawback arising out of the time lag between collection of revenues and subsequent remittance to the Ministry of Finance and the existence of a large number of disparate accounts. Funds accumulated in some accounts whereas in other accounts, there were not enough funds to meet expenditure requirements. The Ministry of Finance as a result, could never have a true picture of the state of finances and progress of expenditure. In order to streamline the cash flow of Government, from the FY 1982/83, all Government revenue accounts were consolidated into a single account and similarly all expenditure were routed through a separate single budget account. Disbursing officers were set drawing limits for every quarter under a Letter of Credit (LC) system. Matching this, a Central Accounts Cell and an Accounts Service were created to streamline accounting.

The third major area of budgetary reform has been in a complete overhaul in the powers of officers to re-allocate funds between different heads of expenditure. This became a necessity with the initiation of the processes of decentralization, which called for a redefinition of the powers of central departments and the dzongkhags. The intention is that in the early stages of decentralization the powers should reflect the objectives of decentralization by providing adequate flexibility to meet local needs while maintaining a reasonably tight control on expenditure to keep these in line with plan priorities.
People's active participation in their own development has been a key policy of His Majesty the Fourth Druk Gyalpo since the Coronation in 1974. Toward this end, several institutions have been established and legislations enacted to empower people, evolving a representative system of governance. The formal organizational structure and procedures for decentralization have evolved over the years. His Majesty the Fourth Druk Gyalpo had established Dzongkhag Yargay Tshogchhung (DYT) in 1981 to promote people's participation in the decision making process and commanded the delegation of a wide range of powers, authority, resources, responsibilities and functions from the central agencies to DYT to formulate, approve and implement dzongkhag and gewog plans activities.

The broad financial parameters emerged by late 1980s as also the overall structure based on which the overall size was tentatively determined. Based on these, detailed discussions were held with various departments and it was possible for Bhutan to make a presentation of the draft Plan for negotiations for funding with the Government of India, the United Nations system (particularly the UNDP) and other donors.

Once the draft Plan was finalized and major commitments of external assistance were reviewed, it was possible to refine the content of programs and projects further. This involved detailed discussions with various departments and all the Dzongkhag Yargay Tshogchungs (DYT). The discussions of the Dzongkhag Plans were conducted under the Chairmanship of His Majesty who personally toured most of the Dzongkhags.

Until the end of Fourth Plan, assistance received from various donors was in the form of grants obviating the need for repayment. Since substantial portion of assistance during the Sixth Plan is coming in as loans, debt servicing and repayment liabilities are of great concern. Therefore, special attention has been given to the accumulation of hard currency reserves and to boost export for hard currency earning. It is envisaged that the foreign exchange requirement is likely to remain limited in the near future. Therefore, the government will resort to borrowing only on the most concessional terms, and also seek for grants as much as possible.

Through the years, there had been changes in the structure of the Government to keep up with the changing conditions and the furtherance of its five-year plans. Accordingly, several instructions were made by the Ministry of Finance to enhance and strengthen the financial management system. In 1985, the Budget Bureau was merged with the Central Accounts Division (CAD) and renamed as Department of National Budget \& Accounts (DNBA) and 
the Royal Audit Department was declared as an autonomous agency called the Royal Audit Authority (RAA).

\subsection{Programme Budget Model}

Towards the end of 1986, the Ministry of Finance introduced a Programme Budget Model to be effective from April 1987 coinciding with the launch of the Sixth Five Year Plan. The Programme Budget Model aimed to facilitate the budgetary process, rationalize budgetary estimates on a programme basis, and improve the accounting system, preparing the way for its eventual computerization.

\subsection{Financial Manual $1988^{4}$}

The Programme Budget Model was integrated in the Financial Manual 1988, which supersedes the 1975 Financial Manual and the then existing financial rules and regulations.

It has become imperative to rewrite the Financial Manual of the Royal Government in view of, inter alia,

i) the volume and complexity of the role of the Government increasing dramatically since 1975;

ii) the need to create a strong and effective administration having a sound financial management system;

iii) the desire to have proper delineation and decentralization of responsibilities at all levels and commensurable accountabilities thereof.

The Financial Manual 1988 aims to:

(i) enhance the efficiency and effectiveness of the financial management system of the Government;

(ii) streamline budgeting and accounting, and reduce and simplify working procedures emphasizing accountability and responsibility;

(iii) ensure uniformity and standardization among all government agencies in accounting and discharging financial transactions, with a view to ascertaining proper receipts and optimum utilization of government funds.

Government agencies, however, may have their own manuals prescribing their working procedures according to their respective functions, provided that they are consistent with the Financial Manual 1988.

The major milestones in implementing decentralization in the country include the formation of the Gewog Yargay Tshogchhung (GYT) in 1991 to promote local socioeconomic development strategies and initiatives by empowering the people to make decisions on their plans and programmes, and by enabling them to adopt approaches and practices adapted to local needs. Both DYT and GYT involve the people in political, social and economic decisions making thus increasing their capacities to set their collective priorities and to initiate means for their fulfillment. Decentralization and participatory development has brought about the following changes:

Devolution of administrative and financial powers, and human resources from the central to the Dzongkhag administration;

- Increased capacity of GYT and DYT to make collective decisions regarding their development plans and its implementation; and

- $\quad$ Autonomy of GYT and DYT to make regulations and legislations applicable within their jurisdictions.

Experiences over the past decades have reinforced the confidence of the Royal Government in the capacities of the communities to plan and implement development activities on their own.

\subsection{Financial Rules and Regulations 2001}

The Royal Government of Bhutan in its effort to promote good governance, attaches great importance to economy, efficiency, accountability and transparency in the management and utilization of public resources. In order to achieve these important objectives, it has become vital that a coherent and consistent set of principles, rules and instructions is available to guide officials in discharging their responsibilities. Since 1988 there have been many new developments in the Royal Government of Bhutan as well as in the field of financial management. Consequently, a thorough revision to the existing manual had become crucial. Towards this end, the MoF undertook series of exercises starting in 1998 and the outcome of this exercises is a set of manuals titled "Financial Rules and Regulations -2001" commonly known as FRR-2001.

The FRR-2001 contains manuals that are structured in a more orderly manner, specifying clearly the roles and responsibilities of concerned officials at all levels.

\section{$2.8 \quad$ Financial Rules and Regulations 2002}

Decentralization in the Bhutanese context began with the delegation of various functions from the central government to the Dzongkhags. With increasing capacity at the Dzongkhags to carry out the functions, the shifting of authority for decision-making has begun. It also became apparent that further delegation of functions and devolution of authority were necessary from the Dzongkhags to the Gewogs. The Dzongkhag Yargay Tshogchhung Chathrim

${ }^{4}$ Royal Government of Bhutan, Financial Manual 1988 
1995 and Gewog Yargay Tshogchhung Chathrim 1995 were revised to Dzongkhag Yargay Tshogdu Chathrim 2002 and Gewog Yargay Tshogchhung Chathrim 2002 respectively. These revised Chathrims contain two annexures viz. ${ }^{5}$

Annexure 1: Financial Rules and Regulations 2002 Changes Applicable to Dzongkhag/Gewog Executed Activities and;

Annexure - 2: Schedule of Delegation of Powers to the Dzongkhag and Gewog levels.

These revised Chathrims institutionalizes changes in the decentralization process whereby greater authority, responsibility and resources for several functions are handed over to the sub-national bodies. The new approach had triggered a gradual conceptual shift from a sector approach to a more Gewog needs based system. It has promoted self-organization at the micro-level, deepening house-to-house direct participation. It has encouraged greater effort from the communities including better use of their own resources as well as enhanced their capacity to absorb more resources from the Government. It also enhanced the roles and scope of GYT and DYT members.

The GYT retain rural taxes and user charges. The main contributions of the rural population have been labor and local materials in beneficiary schemes, which in monetary terms can be quite substantial. Allowing the GYT to retain these revenues has fostered a greater spirit of ownership and participation in development activities. The financial powers of the elected bodies, like the DYT and GYT, were broadened to include prioritization and allocation of annual budget, re-appropriation of budget, review and ratification of accounts of Gewog and Dzongkhag administrations.

The GYT tender committee were empowered financially to award works or procurement orders of a magnitude that were previously reserved for Dzongkhag tender committees. In addition, powers of the Dzongkhag tender committees, in which the elected DYT members participate as members, to award works or procurement order, were also enhanced.

\section{FINANCIAL SYSTEMS}

\subsection{Computerized System of Budget and Accounts (CSBA)}

In 1992 the Ministry of Finance has implemented a computerized system of budget and accounts for the government developed in DOS-based FoxPro called

\footnotetext{
5 Dzongkhag Yargay Tshogdu Chathrim 2002 \& Gewog

Yargey Tshogchhung Chathrim 2002
}

Computerized System of Budget and Accounts (CSBA). This system was used only within Department of Budget and Accounts (DBA), Ministry of Finance (MoF).

The Royal Government's restructuring initiative of $1999^{6}$ defined efficiency, accountability and transparency as the underpinning values of good governance. New institutions responding to emerging needs, some organizational restructuring and mechanisms for internal accountability were established. The structural and staffing components of the Government have been carried out. As recommended, all the ministries have adopted a uniform structure. Policy and Planning Divisions (PPDs) and Administration and Finance Divisions (AFDs) have been established along with a broad organizational grouping with departments, divisions and sections.

A Finance Committee was established. Likewise, the Planning Commission was reconstituted in 1999 under the chairmanship of the Head of the Government.

\subsection{Central Budget \& Accounting (CBA) and Budget \& Accounting System (BAS)}

To cope up with the changing time and technology in the field of public financial management both within the country and around the world, the Ministry of Finance specifically the Department of Budget and Accounts developed two new systems, namely Central Budget and Accounting (CBA) System and Budget and Accounting System (BAS) in 2001 incorporating all the provisions and requirements stipulated in FRR-2001.

These two systems were developed in Client-server environment using Windows NT/2000 and Window 98/ME, SQL Server 2000/MSDE, Visual Basic 6.0, Crystal Report 8.0. and uses Rapid Application Development (RAD) tools and Object Oriented development technology. While CBA system is used only within DBA, all budgetary bodies throughout the country use the BAS.

\section{FISCAL DECENTRALIZATION TO LOCAL GOVERNMENTS}

Fiscal decentralization is the process of devolving fiscal decision-making power and management responsibilities to the local government, giving them a certain degree of discretion and autonomy in resource planning and its mobilization.

Article 22, Section 18 of the Constitution ${ }^{7}$ provides that the Local Governments shall be, inter alia:

\footnotetext{
${ }^{6}$ Good Governance under the themes of efficiency, transparency and accountability, 1999

${ }^{7}$ The Constitution of the Kingdom of Bhutan 2008
} 
(a) entitled to levy, collect, and appropriate taxes, duties, tolls, and fees in accordance with such procedure and subject to limitations as may be provided for by Parliament by law;

(b) entitled to adequate financial resources from the Government in the form of annual grants;

(c) allocated a proportion of national revenue to ensure self-reliant and self-sustaining units of local selfgovernment;

(d) supported by the Government to promote holistic and integrated area-based development planning; and

(e) entitled to own assets and incur liabilities by borrowing on their own account subject to such limitations as may be provided for by Parliament by law.

Article 22 of the Constitution envisages a greater level of fiscal decentralization in the form of annual grants and access to other resources, including borrowings. Towards this, the 10FYP introduced formula-based annual discretionary grants for local governments. While the definition of annual grants is not specified, it has taken the form of an inter-governmental fiscal transfer, i.e. resources transfers from central government to local governments. In the initial periods, the inter-governmental fiscal transfers to local governments (Dzongkhags and Gewogs) have taken the following forms:

(i) Based on a resource allocation formula; and

(ii) Uniform annual grants based on the Constituency

In addition to the resources made available through the formula-based grants, a new element in the form of uniform annual grants was initiated over the years as follows:

\subsection{Constituency Development Grant (CDG)}

This is a grant of $\mathrm{Nu} .2$ million per annum per constituency/Member of the National Assembly introduced during the first democratically elected government in 2008. It is a separate budget head in the annual budget and placed at the disposal of the Members of the National Assembly. Its main purpose was to establish a basis for direct and regular interaction between the Members of the National Assembly and their constituencies. It is expected to support decentralization, strengthen local governance and provide communities with access to small funds that are flexible and be able to meet emergent and unplanned needs expeditiously. However, this was discontinued in 2012 in view of the various concerns and discussions over its effectiveness and efficacy.

${ }^{8}$ The Country Financial Accountability Assessment, 2002

\subsection{Gewog Development Grant (GDG)}

Towards strengthening the decentralization process and good governance at the grass roots level, the second government initiated a new system of Gewog Development Grant of Nu. 2 million per annum per gewog from July 2013 over and above the regular budget of the gewogs. The GDG initiative in general has encouraged greater community participation and vitality in identifying their pressing needs, thereby creating a positive impact in the lives of the people.

\subsection{Dzongkhag Development Grant (DDG)}

From the fiscal year 2016-2017, the government has initiated another grant at the Dzongkhag level called the Dzongkhag Development Grant of Nu. 7 million per annum per dzongkhag. The government has identified the broad areas in which the grant should be used.

Further, to strengthen and deepen the process of decentralization process, the present government has enhanced DDG from $\mathrm{Nu} .7$ million to $\mathrm{Nu} .10$ million with effect from July 2019 with the revised guidelines issued.

\subsection{Annual Grants for Gewogs (AGG)}

The implementation of CDG, GDG and DDG has provided adequate experiences to local functionaries in planning their development needs and properly managing the financial resources. In view of this and in keeping with the international good practices, the present Government decided to reform the practice of allocating budget and introduce Annual Grants for Gewogs.

The Annual Grant is a sum total of all financial resources allocated to Gewogs to achieve their planned programmes, activities as per their needs and priorities and maintaining the existing service infrastructures including services delivery.

\section{PUBLIC FINANCIAL ASSESSMENT/STUDIES}

\subsection{The Country Financial Accountability Assessment (CFAA) 2002}

The Country Financial Accountability Assessment $(\mathrm{CFAA})^{8}$ completed in 2002 identified financial human resource development as one of the priority areas. The CFAA had several recommendations amongst which are adopting the international accounting standards in major public enterprises, drafting laws on financial management and combating corruption, and implementing a fully integrated computerized government accounting system.

The passage of the Public Finance Act can be regarded as a milestone in this direction, as it sets the institutional and legal framework for financial management. The adoption of 
a computerized Budget and Accounting System (BAS) in ministries / agencies, and a Central Budget and Accounting (CBA) system in the Department of Public Accounts and the Department of National Budget has brought about significant improvements in the financial management system.

\subsection{PFM Software Review ${ }^{9}$}

Royal Government of Bhutan has embarked on a comprehensive and time bound initiative to reform its public financial management. The PFM Reform Plan is supported by the World Bank Group through 'Improving Public Financial Management in Bhutan' program. Under this program World Bank aims to strengthen public accounting functions of RGoB. MoF wishes to integrate/ replace all these systems for efficient and effective financial control and reporting. Hence, under this initiative MoF had undertaken a diagnostic assessment of the current systems and processes to chart out a roadmap to move to a modern Integrated Financial Management Information System (IFMIS).

From the key observations and prevailing gaps in the existing software relating to PFM in Bhutan, it is evident that improvements in the methodologies, processes and systems are required for making the PFM systems in Bhutan more efficient and effective. The technology reforms shall support in actuating and institutionalizing the methodology improvements and achieve the desired outcome through implementation of IFMIS. The report contains an assessment of the systems currently being used in MoF as a basis for a recommendation to either continue with the existing systems (with or without major upgrades) or move to a new Customized Off the Shelf (COTS) software.

The conclusion of the assessment is that interfacing/ integrating all the current systems may offer a stop gap solution with limited data collation and consolidation capability but it cannot be used for achieving the long term goals for an effective and efficient public financial management in Bhutan.

\subsection{Expenditure and Financial Accountability (PEFA) Assessment $^{10}$}

The Public Expenditure and Financial Accountability (PEFA) assessment provides a framework for assessing and reporting on the strengths and weaknesses of public financial management (PFM). A PEFA assessment incorporates a PFM performance report that includes an evidence-based measurement of performance against 31

\footnotetext{
${ }^{9}$ Review of PFM Software Systems in Bhutan, Deloitte Touche Tohmatsu India Private Limited

10 www.pefa.org
}

indicators as well as an analysis of the findings and its impact on desirable budgetary and fiscal outcomes. The PEFA methodology draws on international PFM standards and good practices and provides a foundation for reform planning, dialogue on strategy and priorities, and progress monitoring.

\subsubsection{PEFA Assessment 2010}

This assessment of PFM has great relevance in the context of the new democratization of the political processes, the new Parliament and a strong movement towards devolution through the Local Government Act 2009. The budgetary system is intended to support budgetary outcomes in three areas - aggregate fiscal discipline, strategic allocation of resources and efficient service delivery; and any apparent defects need to be looked at against these intentions.

Results for the PEFA Indicators and their dimensions with the less favorable results were noted. This is important to identify where reform attention is worth consideration by the Government. Taking the 2010 PEFA assessment ${ }^{11}$ as its starting point, MoF in 2012 prepared a Public Financial Management Reform Strategy. The strategy has the form of a matrix, organized as per some of the areas and performance indicators (PI) of the PEFA assessment. Some of the key PFM reforms implemented include:

i. Amendment of the Public Finance Act 2007 in 2012

ii. Introduction of web-based application software for PFM systems viz. PlaMS, MYRB, RAMIS, PEMS.

iii. Implementation of online fund transfer system through Electronic Fund Transfer and Clearing System (EFTCS) for salaries and other periodic expenses.

iv. Implementation of Medium Term Fiscal Framework (MTFF) and the creation of a Macroeconomic Framework Coordination Committee (MFCC)

v. A National Internal Control Framework (NICF) developed

vi. Internal Audit Charter and Audit Code of Ethics issued and Internal Audit Manual developed and operationalised.

vii. Implementation of Audit Resource Management System in RAA

viii. A Public Procurement Strategic Framework issued

11 Bhutan Public Financial Management Accountability Assessment Report, June 2010 
ix. Strengthened internal audit Initiated revision of Financial Rules and Regulations

x. Implementation of accounting and auditing standards for public corporations in phased manner.

xi. An Annual Performance Management system introduced.

\subsubsection{PEFA Assessment $2016^{12}$}

The purpose of the assessment of the Public Financial Management (PFM) performance of the Royal Government of Bhutan (RGoB) was threefold:

(i) to assess the quality (strengths and weaknesses) of PFM in the country against generally accepted international standards; to assess progress since the last PEFA assessment in 2010, and

(iii) to provide $\mathrm{RGoB}$ and other stakeholders with a common source of information as a basis for further dialogue on PFM reforms.

This assessment was carried out under the approach of full ownership by RGoB and self-assessment by its officials, with technical support from World Bank and IMF. Since the 2010 PEFA assessment and the implementation of a comprehensive PFM reform program, RGoB has led a wide array of reforms in planning and budgeting, revenue administration, asset and liability management, procurement, internal control, internal audit, reporting, external audit and oversight.

Bhutan has always attached great importance to good governance on principles of accountability, transparency and efficiency. The PFM Reform Program prepared in 2010 has been implemented by a committed government and its development partners. To further improve PFM in the country and take forward the reform agenda, this PFM assessment is expected to be used as a basis for a comprehensive, sequenced and time-bound PFM reform action plan to be supported through a PFM Multi Donor Fund (MDF) that is being established.

\section{MULTI-DONOR FUND FOR PFM (PFM-MDF) ${ }^{13}$}

A Multi Donor Fund is an effective aid modality instrument to support and spearhead Bhutan's PFM reform agenda. In line with the Paris Declaration on Aid Effectiveness (March 2005) and the commitments at the high level forum on Aid Effectiveness in Accra (2008) and Busan (2011), the World

\footnotetext{
12 Public Financial Management Performance Report, September 2016
}

Bank recognizes the advantages of joint cooperation and technical assistance amongst the donors. One of the aid modalities (financing instruments) through which the World Bank endeavors to achieve this is the Multi Donor Fund (MDF) which is funded by donors and administered by the Bank that provides a grant to beneficiaries to implement their reform agenda, thus enhancing country ownership.

Bhutan Multi Donor Fund for PFM Reform Program (PFMMDF) provides a common platform for the Development Partners (DP) to come together and support RGoB in implementing a RGoB-led PFM Reform Program. The MDF could also support a joint dialogue on PFM reforms amongst the DPs. Through various windows under MDF, DPs are able to provide comprehensive support to RGoB by avoiding duplication, reducing administration costs and providing a platform for other DPs to contribute, who, otherwise would not have engaged in PFM individually. The key objective of the Bhutan PFM-MDF is to help RGoB implement its PFM Reform Program in a coordinated and holistic basis and to scale it up. This is done through a basket-funding mechanism by establishing an MDF which provides a common platform for DPs to come together by pooling their resources and efforts in strengthening PFM in Bhutan.

The MDF plays a catalytic role in leveraging knowledge and financing by drawing on the best expertise in the field and working closely with a broad range of partners and stakeholders. This MDF is initially funded by the European Commission (EC) and the Austrian Development Agency (ADA). Going forward, it is expected that other DPs will join the Program and contribute to the Bhutan PFM-MDF.

The overall development objective of PFM-MDF is " $t o$ support strengthening the performance, transparency and accountability in public financial management in Bhutan."

Bhutan became the fifth country in the world to be recognised by Public Expenditure and Financial Accountability (PEFA) framework for maintaining high standards of public financial management (PFM) system. "Bhutan's PFM is at a quite advanced level. But going forward, the government must place continued emphasis," the World Bank Country Director, Qimiao Fan said ${ }^{14}$.

\section{PFM GOVERNANCE GROUP (PFM-GG)}

PFM Governance Group has been constituted in November 2013 under the chairmanship of Finance Secretary with representation from all the departments under the ministry.

\footnotetext{
13 PFM Performance Report, based on PEFA 2016 framework, September 2016

${ }^{14}$ Kuensel issued dated 25.09.2017
} 
It is an apex body to steer the PFM reforms action plan and coordinates the resources required for the implementation of the action plan.

\section{PFM REFORM STRATEGY 2017-2021 15}

Bhutan has been making exemplary progress in building its public financial management systems to provide fiscal discipline, rational allocation of resources in line with FiveYear Plans (FYP), and to support efficient public service. Externally validated assessments of its PFM in 2010 and 2016, using the Public Expenditure and Financial Accountability (PEFA) methodology based on internationally accepted standards, show the achievements over the last six years and the strengths and weaknesses of Bhutan's PFM. Comparison with other countries in the region shows that Bhutan is ahead of the regional average in most areas. However, there are weaknesses and risks in the PFM systems. The PFM Reform Strategy and Action Plan 2017-21 has been prepared to consolidate recent reforms, close gaps, improve transparency and accountability, build domestic revenue, and integrate or interface several stand-alone computerized information systems.

As per the reform strategy and action plan funded under the PFM-MDF project, several major reforms are being implemented like the introduction of Goods and Services Tax (GST), electronic Government Procurement (e-GP) system, development of Integrated Financial Management Information System (IFMIS), implementing electronic payment system, financial reporting using International Public Sector Accounting Standards (IPSAS), strengthening internal audit functions, strengthening capacity of parliamentary committees related to PFM, strengthening accounting and auditing standards board of Bhutan (AASBB), capacity development in PFM etc.

\section{RECOMMENDATIONS}

\subsection{Chart of Accounts (CoA)}

A well-functioning PFM framework includes an effective accounting and financial reporting system to support fiscal policy analysis and budget management. Among other things, government business processes and decisions are anchored on the flow of specific financial information/data between various stakeholders. Providing such information on government activities is an important function of the accounting and reporting system which should capture, classify, record, and communicate relevant, reliable, and comparable financial information for at least the following purposes: budgetary accounting and reporting, including reporting of actual against approved budget estimates; general purpose financial reporting; management information; and statistical reporting.

This system underpins the collection and use of public resources and informs policy makers, managers of government agencies, parliamentarians and the public at large on government policies and operations.

The chart of accounts (CoA) is possibly the most critical element of a well-functioning PFM system. The CoA, although appears to be just concerned with classifying and recording financial transactions, is critical for effective budget management, including tracking and reporting on budget execution. The structure of the budget-in particular the budget classification - and the CoA have a symbiotic relationship. The CoA should be able to be changedparticularly in the context of an Integrated Financial Management Information System (IFMIS) - to respond to changes such as reorganization of government and changing needs.

The chart of accounts has grown in significance for government reporting over the years as country seeks to capture, report and analyze public finance across many different dimensions. The General Ledger (GL) is the centerpiece of any well-formulated PFM system and is structured according to the CoA. Modern accounting systems are built around a GL, with all transactions recorded through the GL and through a number of related sub-ledgers. The GL effectively becomes the central control, which ensures the integrity of the PFM system. The current structure of the object codes is largely aligned to Government Finance Statistics Manual 1986 (GFSM1986) of the International Monetary Fund (IMF).

Currently Department of National Budget (DNB) determines the overall structure of the elements of CoA through budget classification in the Multi-Year Rolling Budget (MYRB) system, which is then replicated in the electronic Public Expenditure Management System ( $e$ PEMS) for budget execution of expenditures. The Revenue Administration and Management Information System (RAMIS) of the Department of Revenue and Customs (DRC) uses revenue classifications. Different agencies are developing different systems and there is a risk that integrating information between the systems will become more of a challenge. The Department of Revenue and Customs (DRC) had already aligned revenue classifications in RAMIS with a GFSM2014 structure. This is structured

\footnotetext{
15 Royal Government of Bhutan, Public Financial Management Reform Strategy 2017-2021, August 2017
} 
very differently from the existing object code structure. Further risk also exists with the Department of National Property (DNP) coming up with the new Asset Management System (AMS) for the Government and we do not know how the coding is structured.

Ideally, all agencies related to the PFM or at least within the Ministry of Finance should confer to agree the appropriate general structure going forward for the entire economic segment and eventually the full CoA. All such systems like MYRB, e-PEMS, e-GP, AMS, RAMIS etc. should interface with the general ledger through a unified CoA. It is suggested that the current IFMIS Core Group be reviewed and re-constituted taking in representation from all relevant agencies to undertake this assignment in a coordinated and holistic approach.

One major challenge in updating the CoA would be ensuring integrity between the new CoA structure and the historical data. Another risk could be lack of proper business continuity plan if it involves change of systems.

\subsection{Letter of Credit (LC) and Treasury Single Account (TSA)}

The Letter of Credit (LC) system had played an important expenditure control role for many years. In the absence of a more effective system, LC became the principal focus to ensure financial control. It also provided a degree of assurance to the spending agencies on the available to them, details of expenditure and balances. Over the years the PFM system has undergone sea change from manual to the present web-based online near real-time system called electronic Public Expenditure Management System (e$P E M S$ ). This enables much tighter expenditure control and enables timely and efficient reporting with reliable report generating capacity available.

The LC system performs a limited function that has already been overtaken by recent reforms. Releases are purportedly made under the LC system to enable spending units and line ministries to enable tracking of expenditures and limit them to the extent of each LC. The efficacy of the LC system is therefore limited only to controlling expenditures based on LCs. Therefore, budget releases should be issued against appropriations, not LCs, and should be oriented to limiting the speed of expenditures over the course of the fiscal year. Section 63 of the Public Finance Act states that "No budgetary body shall make commitments that have financial implications beyond the limits authorized by the Budget and Appropriation Act". So long there is appropriation (though not necessarily LC limit because release would have not been made) the agencies may or could commit but not beyond the Appropriation limit.

In view of the above, it is recommended that appropriations should be the principal focus of expenditure control and reporting. This is especially so because cabinet and parliament are focusing attention on the budget as Bhutan gains experience with democracy and public debate following the 2008 constitutional changes. With the introduction of the quarterly Budget Utilization Plan (BUP) which has been replaced by the more enhanced and user friendly monthly Budgetary Release Forecast (BRF) process, budgetary bodies would plan for their cash requirements and indicate them to the MoF. The MoF, in turn, would allocate based on each appropriation as it currently does under the LC system by segregating them based on agencies codes.

The monthly limit would simultaneously be conveyed to the paying Bank, which would maintain ledger/sub ledger accounts under the TSA. Subsequent spending, reallocations and balances would be monitored based on these appropriations. Based on such appropriations the monitoring and control system would be greatly enhanced with clear linkages between budget, appropriation and expenditures. Abolition of the LC system would anchor the monitoring process to budget appropriations and so enhance control. This will also enable the removal of an additional, but now redundant, level of control and so reduce workload as well.

\subsection{Integrated Financial Management Information System (IFMIS)}

In terms of terminology, an IFMIS usually refers to computerization of public expenditure management processes including budget formulation, budget execution, and accounting with the help of a fully integrated system for financial management of the line ministries and other spending agencies. The full system should also secure integration and communication with other relevant information systems. The complexity of information systems within the government sector is, to a large extent, due to the multiplicity of functions and policy areas.

Ministry of Finance has initiated the process for moving towards the integrated financial management information system some years ago and this work has been further revived under the ongoing PFM-MDF project with the core team for IFMIS formed. The present activities seem to be fetching both financial and non-financial information from various stand-alone systems using either web services or application program interface (API) based on the intended users requirements. The establishment of an IFMIS has consequently become an important benchmark for the country's budget reform agenda, often regarded as a precondition for achieving effective management of the budgetary resources.

The improved recording and processing of government financial transactions allows prompt and efficient access to 
reliable financial data. This supports enhanced transparency and accountability of the executive to parliament, the general public, and other external agencies.

IFMIS also strengthens financial controls, facilitating a full and updated picture of commitments and expenditure on a continuous basis. Once a commitment is made, the system should be able to trace all the stages of the transaction processing from budget releases, commitment, purchase, payment request, reconciliation of bank statements, and accounting of expenditure. This allows a comprehensive picture of budget execution.

IFMIS also provides the information to ensure improved efficiency and effectiveness of government financial management. Generally, increased availability of comprehensive financial information on current and past performance assists budgetary control and improved economic forecasting, planning, and budgeting.

\section{IFMIS is a management tool.}

When developing an IFMIS it is important that it cater to management needs - not just those of the central agencies, but also line agencies. Moreover, as a management tool it should support the management of change. It must be viewed as an integral part of budget system reform - hence not be designed just to meet present requirements, but also to support those needs that are likely to arise as parallel budget reforms are implemented.

\section{It should provide a wide range of nonfinancial and financial information.}

As a tool of management it should provide the information required for decision making. For this purpose it is anchored in the government accounting system, and should be designed to perform all necessary accounting functions as well as generate custom reports for internal and external use. However, this does not mean that it should exclusively concentrate on financial information. Managers will require other nonfinancial information. For example, personnel information such as numbers of employees, their grade within the organizational structure and rates of remuneration. For performance-based budgets, performance information will be important to managers, such as the identification of programs, the objectives or outcomes of programs, the types of goods and services produced, as well as indicators by which to judge the efficiency and effectiveness of programs.

\section{It is a system.}

Its role is to connect, accumulate, process, and then provide information to all parties in the budget system on a continuous basis. All participants in the system, therefore, need to be able to access the system, and to derive the specific information they require to carry out their different functions. The converse is also true, if the IFMIS does not provide the required information - that is, has not the right functionality - it will not be used, and will cease to fulfill its central function as a system. Further, by automating procedures and internal controls, it strengthens financial controls and promotes accountability

In view of the above, it is recommended that Ministry of Finance to adopt a comprehensive approach in the development of IFMIS to ensure that all functional interdependencies are identified, hence securing the capture of all related information flows.

\subsection{Adoption of cash-basis IPSAS financial reporting}

The RGoB intends to enhance the quality and transparency of its Annual Financial Statements (AFS) by adopting cashbasis International Public Sector Accounting Standards (IPSAS). The need for accounting reforms is underscored by the Public Expenditure and Financial Accountability (PEFA) Assessment 2016 of Bhutan as the dimension 29.3 on Annual financial reports - Accounting Standards was rated " $\mathrm{C}$ ".

Considering the limitation in the current capacity and information system, the RGoB plans to adopt IPSAS in a graduated manner starting with adoption of Cash-basis IPSAS. This initiative is being supported under PFM MDF project. The presentation of national annual financial statements consistent with international standards is one of the Project Development Objectives (PDO) indicators to be completed by project closing of January 31, 2021. An international consultancy firm is assisting $\mathrm{RGoB}$ in implementing the IPSAS reforms. The diagnostic report to guide the process has been prepared and the consultants are currently supporting RGoB on capacity building. Based on the progress made, the annual financial statements of FY2020-21 are expected to be compliant with cash-basis IPSAS.

To institutionalize the adoption of Cash-basis IPSAS, it is important that the requirement is embedded in the legal framework of Bhutan. This has been notified as prior action trigger for the current Development Policy Credit (DPC) series. Accordingly, it is recommended appropriate accounting standards/provisions/clauses be included in the upcoming revised FRR.

\section{REFERENCES}

[1] RGoB, Ministry of Finance: www.mof.gov.bt

[2] RGoB, GNHC www.gnhc.gov.bt: Five Year Plan documents.

[3] RGoB, Ministry of Home Affairs: Dzongkhag Yargay Tshogdu Chathrim 2002 
[4] RGoB, Ministry of Home Affairs: Gewog Yargay Tshogchhung 2002

[5] RGoB, Ministry of Finance: Public Finance Act of Bhutan 2007

[6] RGoB, Ministry of Home and Cultural Affairs : The Local Governments' Act of Bhutan, 2007

[7] The World Bank, South Asia Region Financial Management Unit: Bhutan Public Sector Accounting and Auditing - A Comparison to International Standards, May 2007

[8] RGoB, Ministry of Home and Cultural Affairs: The Local Governments' Act of Bhutan 2009

[9] The World Bank: Bhutan Public Financial Management Accountability Assessment June 2010

[10] ADB: Financial Sector Development Project - Improving Accounting and Auditing Standards in Bhutan, Ernst \& Young, 2010.

[11] ADB: Strengthening Public Financial Management Project, Maxwell Stamp Limited, Bangladesh, January 2010

[12] ADB: Strengthening Public Financial Management Drafting Consolidated Fund Bill for the Government of Bhutan, Deloitte Touche Tohmatsu India Ltd., December 2010.

[13] IMF, FAD: A Proposal for Medium Term Cooperation on Public Financial Management Priorities, Holger van Eden, Richard Emery and Suhas Joshi, November 2012

[14] RGoB, MoF: Public Finance (Amendment) Act of Bhutan, 2012

[15] The World Bank: Improving PFM in Bhutan - Review of PFM Software Systems in Bhutan, Deloitte Touche Tohmatsu India Pvt. Ltd., 2014.

[16] IMF, FAD: Modernization of Accounting and the Chart of Accounts, Mark Salins, March 2016

[17] The World Bank: Public Financial Management Performance Report based on PEFA 2016 Framework, September 2016

[18] RGoB, Department of Local Governance: Fiscal Decentralization in Bhutan, Lam Dorji, 2017

[19] RGoB, Ministry of Finance: Public Financial Management Reform Strategy 2017-2021, August 2017 